\title{
PERSPEKTIF KELUARGA DAN PERAWAT TENTANG KEMITRAAN KELUARGA DALAM MERAWAT PASIEN DI INTENSIVE CARE UNIT (ICU)
}

\section{Family and Nurse Perspectives on Family Partnerships in Caring for Patients in Intensive Care Units (ICU)}

\author{
Sri Indah Ekowati ${ }^{1}$, Hery Djagat Purnomo ${ }^{2}$, Reni Sulung Utami ${ }^{3}$ \\ ${ }^{1}$ Magister Keperawatan Universtas Diponegoro, RSUP dr. Kariadi \\ ${ }^{2}$ Fakultas Kedokteran Universitas Diponegoro, RSUP dr. Kariadi \\ ${ }^{3}$ Departemen Keperawatan, Fakultas Kedokteran Universitas Diponegoro \\ Korespondensi : indah.wtr@gmail.com
}

\begin{abstract}
ABSTRAK
Perawatan pasien di Intensive Care Unit (ICU) tidak hanya melibatkan petugas kesehatan, tetapi juga memerlukan peran keluarga. Keluarga juga mengalami stres dan kecemasan selama menunggu pasien di ICU. Patient-Family Centered Care (PFCC) merupakan paradigma baru dalam pelayanan kesehatan yang menempatkan pasien dan keluarga sebagai fokus pemberian asuhan keperawatan. Kemiraan keluarga sangat berperan dalam merawat pasien di ICU. Penelitian ini bertujuan untuk mengeksplorasi perspektif keluarga dan perawat tentang kemitraan keluarga dalam merawat pasien di ICU. Desain penelitian adalah kualitatif dengan pendekatan fenomenologi intepretatif. Informan adalah 10 perawat ICU dan 10 keluarga pasien sesuai dengan kriteria inklusi dan ekslusi yang diambil dengan metode purposive sampling. Penelitian dilakukan di Rumah Sakit Umum Pusat di Kota Semarang pada bulan April sampai Mei 2018. Analisis data dengan teknik intepretative phenomenological analysis (IPA). Hasil penelitian menunjukkan 4 tema utama tentang makna kemitraan keluarga, bentuk kemitraan keluarga, pengaruh kemitraan keluarga, dan tantangan penerapan kemitraan keluarga di ICU. Kemitraan antara perawat dan keluarga diartikan sebagai keadaan dimana perawat sebagai sumber informasi tentang kondisi pasien, perawat memberikan dukungan dan menghargai keluarga, kolaborasi antara pasien dan perawat, partisipasi keluarga dalam memberi dukungan bagi pasien, keluarga bisa mengungkapkan perasaanya pada perawat. Kemitraan keluarga meningkatkan kenyamanan pasien, tetapi mempengaruhi pemberian asuhan keperawatan dan menambah beban kerja perawat. Perspektif keluarga tentang perawatan ICU dan ketidaksiapan perawat menjadi tantangan penerapan kemitraan keluarga di ICU. Kesimpulan dari peneliian ini adalah keluarga dan perawat memahami makna dan pengaruh kemitraan dalam merawat pasien di ICU, tetapi masih terdapat tantangan dan hambatan dalam penerapannya.
\end{abstract}

Kata Kunci : intensive care unit, perawat, keluarga, kemitraan 


\begin{abstract}
The care of Intensive Care Unit (ICU) patients not only involves health workers, but also requires a family role. Families also experience stress and anxiety while waiting for patients in the ICU. Patient-Family Centered Care (PFCC) is a new paradigm in health services that place patients and families as the focus of providing nursing care. Family partnership plays a role in treating patients in the ICU. Dessign of the study was a qualitative study using intepretative phenomenology. Informants were 10 ICU nurses and 10 families of patients who met the inclusion and exclusion criteria taken by purposive sampling technique. The study was at General Hospital in Semarang from April to May 2018. Data were analyzed with analytical phenomenology interpretation technique (IPA). The results showed that 4 main themes, meaning of family partnership, form of family partnership, the effect of family partnership, and challenges of family partnership implementation in ICU. Partnerships with caregivers and families of ICU patients consist of 5 main categories. Family partnership between nurse and family is defined as nurses as a source of information about the patient's condition, nurses provide support and respect for the family, collaboration between patient and nurse, family participation in providing support for the patient, the family can express their feelings to the nurse. Family partnerships improve patient comfort, but affect the nursing care and increase the workload of nurses. A family perspective and nurse preparedness poses challenges to family practice in the ICU. The conclusion of this study is that families and nurses understand the meaning and influence of partnerships in caring for patients in the ICU, but there are still challenges and obstacles in their application.
\end{abstract}

Keywords: intensive care unit, nurse, family, partnership 


\section{PENDAHULUAN}

Intensive Care Unit (ICU) merupakan salah satu ruang perawatan di rumah sakit dengan staf dan perlengkapan yang khusus dengan tujuan untuk terapi pasien-pasien yang menderita penyakit kritis, cedera atau kompikasi yang mengancam nyawa. Pasien Intensive Care Unit (ICU) umumnya berada dalam kondisi yang mengancam jiwa, tidak menyadari tingkat keparahan kondisinya, atau tidak ingat bahwa mereka sedang dirawat di ICU. Pemberian perawatan di ICU selama ini berpusat pada pasien, terutama berfokus pada kebutuhan fisiologis (Balley, 2010).

Pasien dengan keadaan kritis tidak hanya mengalami berbagai masalah fisik seperti nyeri, sesak nafas, penurunan berat badan, gangguan aktivitas tetapi juga mengalami gangguan psikososial dan spiritual, sehingga perlu adanya dukungan terhadap kebutuhan psikologis, sosial dan spiritual. Proses pemenuhan kebutuhan ini, tidak hanya dilakukan oleh tenaga medis, perawat maupun fisioterapi, tetapi juga memerlukan kemitraan keluarga. Pelayanan keperawatan mengusahakan sumber dukungan dari keluarga pasien dengan penerapan model Patient-Family Centered Care (PFCC) di ICU. Patient-Family Centered Care (PFCC) merupakan paradigma baru dalam pelayanan kesehatan yang menempatkan pasien dan keluarga sebagai fokus pemberian asuhan keperawatan (Beer, 2017).

Keuntungan dari implementasi PFCC antara lain : pasien dan keluarga menjadi pusat pelayanan keperawatan dan aktifitas pelayanan, sehingga pemberian pelayanan lebih efektif dengan orang yang tepat dan waktu yang tepat; meningkatkan kontinuitas perawatan dan integrasi tenaga kesehatan profesional dalam berkolaborasi untuk kepentingan pasien. Hal ini akan meningkatkan otonomi pasien dan keluarga dalam perawatan kesehatan dan meningkatkan kontinuitas dalam pelayanan. Akan tetapi, hal ini belum sepenuhnya dipahami dan dapat diterapkan bahwa Kemitraan keluarga adalah komponen penting dalam perawatan pasien di ICU.

Fenomena terkait pelibatan keluarga dalam perawatan pasien di ICU adalah hal kompleks dan perlu perhatian khusus. Meningkatnya kecemasan pasien, adanya batasan jam kunjung, kebutuhan informasi tentang perawatan, dan dampak hospitalisasi pasien di ICU terhadap keluarga pasien juga merupakan fokus pemberian asuhan keperawatan (Baning, 2012). Hal ini merupakan landasan penting dalam penerapan PFCC, dimana keterlibatan keluarga memiliki peran penting dalam pemeberian asuhan, dengan harapan dapat meinngkatkan otonomi pasien dan keluarga dalam pengambilan keputusan tentang perawatan dan meningkatkan kontinuitas dalam peyanan kesehatan.

\section{TUJUAN PENELITIAN}

Tujuan dari penelitian ini adalah untuk mengidentifikasi perspektif perawat dan keluarga tentang makna kemitraan keluarga dalam merawat pasien kritis di Intensive Care Unit (ICU)

\section{METODE PENELITIAN}

Desain

Penelitian ini menggunakan desain riset kualitatif dengan pendekatan fenomenologi. Pendekatan fenomenologi yang digunakan yaitu fenomenologi intepretatif.

\section{Populasi dan Sampel}

Populasi penelitian adalah seluruh perawat dan keluarga pasien yang berada di ICU Rumah Sakit Umum Pusat dr. Kariadi Semarang. Sampel atau informan diambil dengan menggunakan teknik purposive sampling sesuai dengan kriteria inklusi. Kriteria inklusi untuk perawat adalah perawat dengan Perawat Klinis level II (PK-II) dan minimal bekerja selama 1 tahun di ICU, sedangkan kriteria inklusi untuk keluarga pasien adalah keluarga inti atau penanggungjawab pasien, usia lebih dari 18 tahun atau sudah menikah, dan menunggu pasien ICU selama >36 jam. Jumlah informan dalam penelitian ini adalah 10 perawat ICU dan 10 partisipan dari keluarga pasien.

\section{Tempat dan Waktu Penelitian}

Penelitian dilakuakan di ruang ICU salah satu Rumah sakit umum pusat di Semarang selama 4 minggu pada tahun 2018.

\section{Instrumen dan Prosedur Pengukuran}

Instrumen yang digunakan dalam penelitian ini adalah panduan wawancara, lembar observasi, dan peneliti sendiri sebagai pewawancara. Peneliti membuat kesepakatan dengan partisipan mengenai waktu dan tempat untuk melakukan wawancaraPeneliti 
mengingatkan kembali kontrak atau kesepakatan yang telah dibuat untuk melakukan wawancara. Wawancara dilakukan sekitar 3040 menit untuk setiap partisipan, dilakukan sebanyak 2-3 kali pertemuan sampai peneliti mendapatkan data yang sesuai dengan tujuan penelitian. Hasil wawancara mendalam direkam dengan menggunakan alat perekam (voice recorder) untuk memudahkan peneliti menampung semua jawaban dari partisipan dan sebagai dokumentasi. Wawancara dihentikan setelah tidak muncul lagi informasi baru sehingga data dianggap jenuh atau tersaturasi.

\section{Analisa Data}

Penelitian ini menggunakan pendekatan intepretative phenomenological analysis (IPA). Proses pengolahan data melalui proses intepretatif, yang mana peneliti berperan menafsirkan ucapan partisipan.

\section{HASIL PENELITIAN}

\section{Karakeristik Partisipan}

Perawat ICU yang menjadi partisipan dalam penelitian ini berjumlah 10 perawat yang terdiri dari 3 Ners dan 7 perawat dengan pendidikan D3 keperawatan. Semua perawat adalah perawat level 3 dan merupakan PPJP (Perawat Penanggung Jawab Pasien) yang ratarata sudah berdinas antara 6-14 tahun di ICU

Keluarga pasien ICU yang menjadi partisipan dalam penelitian ini juga berjumlah 10 orang yang memenuhi kriteria inklusi dengan usia antara 29 tahun hingga 63 tahun. Lama tunggu keluaga di ICU berkisar antara 3 hari sampai 1 bulan perawatan.

\section{Hasil Analisa}

Makna kemitraan keluarga dalam merawat pasien kritis di ICU mencakup berbagi informasi tentang kondisi pasien, perawat memberikan dukungan dan menghargai keluarga, perawat bekerjasama dengan keluarga pasien kritis, keluarga berpartisipasi dalam memberi dukungan bagi pasien, keluarga bisa mengungkapkan perasaannya pada perawat. Perawat menyatakan bahwa "...kemitraan berarti kita harus selalu memberikan informasi terkini terkiat dengan perkembangan pasien. Terutama sama penanggungjawab pasiennya dan keluarga yang berhak di berikan inform consent oleh pihak rumah sakit. Keluarga juga harus memberi keterangan yang jujur tentang pasien..." Sedangkan keluarga pasien menyatakan bahwa "...kemitraan berarti komunikasi dan pemberian informasi dari perawat kepada keluarga dan sebaliknya..." Sebagian besar perawat dan keluarga memaknai kemitraan sebagai perawat kerja sama, komunikasi, dan partisipasi antara perawat dan keluarga pasien.

\section{PEMBAHASAN}

Hasil penelitian ini menunjukkan bahwa keluarga dan perawat memahami kemitraan dalam 4 kategori utama. Perawat dan keluarga memaknai kemitraan menyangkut aspek komunikasi dan berbagi informasi, pemberian dukungan, penghargaan, dan kerja sama. Sedangkan aktivitas yang merupakan bentuk kemitraan keluarga digambarkan meliputi pemberian dukungan, mendampingi pasien, proses pengambilan keputusan dan memenuhi kebutuhan dasar pasien (Kean \& Marion, 2014).

Kemitraan diartikan sebagian suatu hal dimana perawat sebagai sumber informasi tentang kondisi pasien. Informasi tersebut bisa berupa kondisi terkini pasien, edukasi tentang hal yang hrus dilakukan keluarganya, alat-alat yang digunakan kepada pasien, dan tindakan yang diberikan kepada pasien. Perawat memberikan dukungan dan menghargai keluarga. Perawat menghargai keberadaan keluarga, perawat memberikan dukungan agar keluarga selalu tabah, dan perawat mempunyai hubungan yang lebih kepada keluarga. Kolaborasi antara keluarga dan perawat untuk mencapai tujuan yang sama yaitu peningkatan kesehatan pasien (Baning, 2012).

Penelitian oleh Beer menyebutkan bahwa family care diartikan dalam konsep kebersamaan, kemitraan, respek dan menghormati. Kemitraan disebutkan sebagai interaksi antara keluarga dan petugas kesehatan di ICU. Beer menemukan bahwa keluarga sangat penting dilibatkan pada perawatan pasien ICU. Keluarga akan diberikan informasi mengenai keadaan pasien sehingga keluarga dapat menentukan tindakan apa yang diberikan kepada pasien. Keluarga juga membutuhkan informasi dari perawat mengenai anggota keluarganya sehingga keluarga dapat berdiskusi dengan perawat. Keluarga dapat memberikan informasi mengenai segala sesuatu tentang pasien yang tidak diketahui perawat.

Teori PFCC menyebutkan bahwa pasien dan keluarga termasuk satu rangkaian dasar, 
yang mana petugas kesehatan sebagai leader yang berkolaborasi dengan pasien dan keluarga dalam pemberian asuhan, perkembangan program perawatan, implementasi dan evaluasi,serta edukasi (Beer, 2011). Selain itu, dalam penelitian ini muncul pernyataan bahwa salah satu makna kemitraan adalah keluarga bisa menyampaikan perasaannya kepada perawat, hal ini sesuai dengan penelitian yang menyatakan bahwa salah satu kebutuhan keluarga selain bertemu dengan dokter adalah kebutuhan berkomunikasi dengan perawat. Hal ini juga berkaitan dengan aspek otonomi keluarga dan proses pengambilan keputusan tentang perawatan pasien (Olding, 2015).

\section{KESIMPULAN}

Implikasi

Implikasi keperawatan dari tema ini adalah pentingnya membina hubungan saling percaya dengan klien dan keluarga pasien di ICU, karena kunci utama dari keberhasilan kemitraan adalah pada komunikasi. Perawat perlu meningkatkan empati dan caring pada keluarga pasien. Kegiatan yang dapat dilakukan oleh perawat ICU adalah mengadakan program diskusi berkelompok antara perawat dan keluarga-keluarga pasien ICU secara rutin, memberikan ruang untuk bercerita, menyampaikan masalah dan kebutuhannya selama menunggu pasien di ICU.

\section{Keterbatasan}

Keterbatasan dalam penelitian ini adalah konfirmasi data, informasi yang didapatkan dirasa kurang mendalam, belum sepenuhnya menggambarkan secara spesifik dan rinci tentang perspektif keluarga dan perawat tentang kemitraan keluarga dalam merawat anggota keluarganya yang sakit.

\section{DAFTAR PUSTAKA}

Azzahratul Kamaliah. (2011). Dukungan Keluarga Terhadap Pasien Yang Dirawat Di Unit Perawatan Intensif Rsup H. Adam Malik Medan. Univ Sumatera Utara. 1-3.

Bailey JJ, Sabbagh M, Loiselle CG, et al. Supporting families in the ICU: A descriptive correlational study of informational support, anxiety, and satisfaction with care. Intensive Crit Care Nurs 2010; 26: 114-122.

Baning KM. (2012). Outcomes Of A Comprehensive Patient And Family-
Centered Care Program In An Adult Intensive Care Unit: A Practice Inquiry Submitted to the Faculty of the College Of Nursing In Partial Fulfillment of the Requirements For. 2012; 0-99.

Beer J De \& P Brysiewicz. (2017). The conceptualization of family care during critical illness in KwaZulu-Natal, South Africa. Health SA Gesondheid, (22). P. 2027

Kean S \& Marion M. (2014). How do Intensive Care Nurses Perceive Families in Intensive Care? Insights from the United Kingdom and Australia. Journal of Clinical Nursing.

Kingsinger V. (2012). Family Centered Care in ICU Settings. Honor Theses. 17.

Mitchell ML, Coyer F, Kean S, et al. (2016). Patient, family-centred care interventions within the adult ICU setting: An integrative review. Aust Crit Care. 29: 179-193.

Olding M, Sarah E M \& Scott R. (2015). Patient and Family Involvement in Adult Critical and Intensive Care Settings: A Scoping Review. Health Expectations, 19. P. 1183-1202.

Ranse K, Bloomer M, Coombs M, et al. (2016). Family centred care before and during lifesustaining treatment withdrawal in intensive care: A survey of information provided to families by Australasian critical care nurses. Aust Crit Care. 29: 210-216.

Statement P. (2012). Patient- and FamilyCentered Care and the Pediatrician's Role. Pediatrics; 129: 394-404.

Van Mol, et all. (2016). Patient and FamilyCentered Care In The Intensive Care Unit, A Challenge In The Daily Practice Of Healthcare Professionals

Wong P, Liamputtong P, Koch S, et al. (2015). Families' experiences of their interactions with staff in an Australian intensive care unit (ICU): A qualitative study. Intensive Crit Care Nurs. 31: 51-63. 